http://revped.ise.ro

Print ISSN 0034-8678; Online ISSN: 2559 - 639X

\title{
THE EUROPEAN DIMENSION OF THE COMPETENCE- BASED SCHOOL EDUCATION IN UKRAINE
}

DIMENSIUNEA EUROPEANĂ A UNEI ABORDĂRI CENTRATE PE COMPETENȚE ÎN ȘCOALA UCRAINEANĂ

\section{Olena LOKSHYNA}

\author{
Journal of Pedagogy, 2018 (1), 47 - 64 \\ https://doi.org/10.26755/RevPed/2018.1/47
}

The online version of this article can be found at: http://revped.ise.ro/category/2018-en/

\section{(c) (i) (2) (2) \\ BY NC SA}

This work is licensed under the Creative Commons Attribution-NonCommercial-ShareAlike 4.0 International License.

Published by:

\section{INSTITUTUL DE ȘTIINȚE ALE EDUCAȚIEI}

http://www.ise.ro/

Further information about Revista de Pedagogie - Journal of Pedagogy can be found at:

Editorial Policy: http://revped.ise.ro/editorial-policy/

Author Guidelines: http://revped.ise.ro/the-writer-guide-2/ 


\title{
THE EUROPEAN DIMENSION OF THE COMPETENCE-BASED SCHOOL EDUCATION IN UKRAINE
}

\author{
Olena Lokshyna* \\ Institute of Pedagogy of the NAES of Ukraine \\ Kiev / Ukraine \\ luve2001@hotmail.com
}

\begin{abstract}
The adoption of the Lisbon Strategy (2000) and of the European Reference Framework on Key Competences for Lifelong Learning (2006) launched a competence-based approach in the EU member states education systems. During the last decade the concept of competence greatly influenced the education policy, school curricula and assessment models. The competence approach serves as an Europeanisation tool harmonising the education systems in order to raise their quality and, thus, to make the EU economy competent in the world. The Ukrainian education is under great influence of pan-European tendencies and policies that results in its Europeanisation. The competence approach is one of the tools of this process at the level of school education. Ukraine has travelled long pass from the discussion and definition of competences to the selection and adoption at the nationwide level. Still, this process is accompanied by a number of challenges that make the European experiences significant for the Ukrainian education in the process of its integration into the European education space.
\end{abstract}

Keywords: competence education, European education space, Europeanization, key competences, secondary education, Ukrainian education.

* Professor, Doctor of Science in Education, Head of the Department of Comparative Education of the Institute of Pedagogy of the National Academy of Educational Sciences of Ukraine, Kyev. 


\section{Rezumat}

Aprobarea Strategiei de la Lisabona (2000) şi a Cadrului european al competen elor cheie pentru învă area pe tot parcursul vie ii (2006) au început procesul de implementare a abordării centrate pe competen e $\hat{\imath} n$ educa ia statelor membre a Uniunii Europene. In ultimul deceniu, acest tip de demers a influen at puternic politicile educa ionale, curriculumul, programele de educa ie si modelele de evaluare. Abordarea centrată pe competen e serveşte drept mijloc de europenizare în vederea armonizării sistemelor educa ionale pentru a îmbunătă $i$ calitatea lor şi astfel, pentru a transforma economia UE în sensul creșterii competitivită ii sale. Educa ia ucraineană este în mare măsură influen ată de tendin ele şi politicile pro-europene, care conduc spre europenizare. Abordarea centrată pe competen e este unul dintre instrumentele acestui proces la nivelul învă ământului școlar. Ucraina a parcurs un drum lung de la discu ii şi definirea conceptului de competen ă la selectarea şi aprobarea la nivel na ional. In acelaşi timp, acest proces este înso it de o serie de provocări, care fac experien ele europene importante pentru educa ia din Ucraina în condi iile integrării sale în spa iul educa ional european.

Cuvinte-cheie: competen e cheie, educa ia bazată pe competen e, educa ia ucraineană, europenizare, învă ământul secundar, spa iul educa ional european.

\section{Introduction}

In 2000 the European Union (EU) adopted the development plan known as the Lisbon Strategy/Lisbon Agenda (2000). The goal was to make the EU the most competitive and dynamic knowledge-based economy in the world capable of sustainable economic growth, better jobs and greater social cohesion by 2010. In the Chapter entitled "Education and Training for Living and Working in the Knowledge Society" it was proclaimed that "a European framework should define the new basic skills to be provided through lifelong learning as a key measure in Europe's response to globalization and the shift to knowledge-based economies, and emphasized that people are Europe's main asset" (Lisbon European Council 23 and 24 March 2000 Presidency Conclusions, 2000). In 2006 the European Parliament and Council adopted "The European Reference Framework on Key Competences for Lifelong Learning", and recommended Member States to ensure that initial education and training offers all young people the means to master the key competences necessary for adult life (Recommendation of the European Parliament and 
of the Council of 18 December 2006 on key competences for lifelong learning -2006/962/EC).

The publication of the document officially launched the process of a competence approach implementation for education by the Member States. As indicated in the European Commission, EACEA, and the Eurydice Report "Developing Key Competences at School in Europe: Challenges and Opportunities for Policy" (2012), the majority of EU countries developed national strategies or put in place centrally coordinated initiatives to support the implementation of the competence approach. Ten years after the adoption of the European Reference Framework the EU took the decision to adjust the document to the new economic, social, and technological realities. The mail goal is to intensify the further implementation of the competence-based approach in education by the Member States, as stated in the Consultation Strategy "Review of the 2006 Framework of Key Competences for Lifelong Learning" (2017, p. 8).

Education in Ukraine is under great influence of pan-European tendencies and policies promoting its integration into the European educational space. The competence approach is one of the tools of this process at the level of school education.

The aim of the article is to study the implementation of a competence-based school education in EU and its impact on Ukraine under the Europeanization process. The latter is accelerating after the signing the Association Agreement which took place between the European Union and Ukraine in 2014. The Agreement had finally confirmed the European vector of the Ukrainian education development and intensified its harmonisation with the European standards.

\section{Conceptual framework}

The hypothesis of the study is based on the concept of Europeanization and Europeanization of education in particular. An issue of education's Europeanization is studied in depth in the works of many European scholars. In particular, in the book "Europeanizing Education: Governing a New Policy 
Space" (2012), Martin Lawn and Sotiria Grek have characterized its essence from the standpoint of multidimensionality, which encompasses the development of:

- a new space of activities, thinking, politics by means of networks, associations, structures within the EU borders, strengthening the role of national actors in the design of this space through the interpenetration of political ideas, knowledge, data and practices;

- a common policy or educational space as a result of general regulation by the EU through the open method of coordination (Lawn, \& Grek, 2012,pp. 8-9).

In their opinion, the Europeanization tools comprise setting common goals (strategic documents) for achievement, as well as the introduction of tools for measuring progress in this process (benchmarks, indicators, standards) in order to harmonize educational systems. Education and Training 2020 Program is named the strategic framework for Europeanisation of educational policies in the EU member states.

The European Reference Framework of Key Competences for Lifelong Learning (2006) plays an important role for Europeanization at the secondary education level.

For our study, the scholars' findings on the Europeanisation impact beyond EU borders is important. S. Greck and M. Lawn write about Europeanization outside the EU in the context of the activities of international organizations. Marko La Rosa, specifying this impact, structures it into two groups:

- direct (in the format of policies), which comprises the implementation of programs, standards, tools (to measure their level of mastery), similar to those implemented in the EU;

- indirect (agents): the influence of institutions, students, teachers, nongovernmental structures and best practices from the EU outside its borders; mobility and exchanges (La Rosa, 2017, p. 45).

Taking into consideration all the aforementioned information, we can argue that EU competence education model has a strong impact on education in Ukraine in the Europeanization context. 
Theoretical methods have been used for this study. Analysis, synthesis, generalization, explanation made it possible to present the competence-based approach in the EU and in Ukraine. The method of comparison has given an opportunity to find the common in this process as well as to underline the specific. It should be noted that the comparison in the research has some limitations because two non-alignable objects are compared, i.e. the EU as a supranational entity, consisting of twenty-eight Member States and Ukraine as a single state. Therefore, the comparative analysis has been carried out at the level of education policy in order to present the strategic dimension of the competence-based education. The legislation and education strategic documents of the EU and of Ukraine as well as theoretical works of the European and Ukrainian scholars have been studied in the process of this research.

\section{Competence-based approach in the EU education}

It is recognised that the concept of "competence" has Greek and Latin

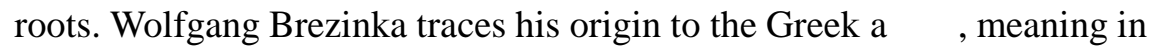
ancient Greek "superiority", "virtue", "skill”. Emphasizing the importance of "superiority" which is predominant at the initial stage, the scholar notes that in this sense the root of the word became the basis of a new "aristos"

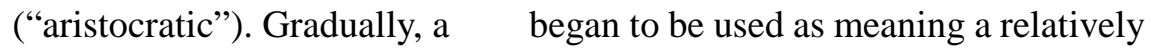
constant quality of a person valued by society (Smith, 2005).

Martin Mulder, Tanja Weigel and Kate Collins compare the concept of

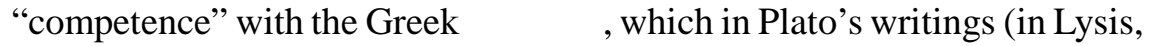
$380 \mathrm{BC}$ ) used in the sense of the quality of personality to achieve something. Later, it appears in Latin in the form of "competens" interpreted as "ability". In the $16^{\text {th }}$ century the concept was already used in English, French and Dutch (Mulder, Weigel, \& Collins, 2006).

According to Paul Hager, the evolution of the "competence" concept can be divided into the following conceptual stages:

- 1960s - 1970s: behavioural interpretation of the concept where competence is understood as a demonstration of activity; 
- 1970s - 1990s: competencies are interpreted as general skills determining the nature of future activities or the implementation of certain actions;

- since the 1990s: competence has begun to be regarded as requiring both an element of performance as well as the possession of certain intellectual, moral and social qualities by an individual (Hager, 1998, p. 413).

The idea of the competence-based education is associated with Noam Chomsky and his theory of language introduced in the 1960s in the USA. The scientist has concluded that "performance" is the basic characteristic when constructing and verifying various competency theories (Zimnyaya, 2004, p.14).

However, the influence of behaviourism had a negative effect on the development of the idea of competence-based education in the United States (Biemans, Nieuwenhuis, Poell, Mulder, \& Wesselink, 2017, p. 2).

In Europe, starting with the 1970s, another model was introduced. It is grounded on a constructivist theory, according to which individuals construct their reality based on the environment which interacts with them. Contrary to the behavioural concept of "stimulus - reaction", constructivism considers learning as a process of reorganizing existing information by an individual for integration and building new cognitive structures. The purpose of education in this context is to create conditions for the pupils' interpretation of environment in the process of his/her interaction with the latter in order to construct his/her own model of knowledge. Competences are viewed as tools for achieving this.

The lengthy discussions have made it possible to distinguish the following four basic characteristics of a competence:

- context is necessary for the demonstration of a competence;

- competence is always a result; it is a characteristic of what an individual can do, rather than the description of the process during which the individual acquires this competence;

- clearly defined standards are required to measure the individual's ability to do something;

- competence is a measure of what an individual can do at a given time (Smith, 2005). 
The definition of the essential characteristics of competencies made it possible to move to their classification. A significant contribution has been made in this matter by the leading international organizations: Council of Europe, Organisation for Economic Cooperation and Development (OECD), EU, etc.

For instance, in 1996 in the report "Key competencies in Europe" delivered by Walo Hutmacher, the Council of Europe presented a list of key competencies structured in five groups, including:

- political and social competences (ability to take responsibility, resolve conflicts peacefully, participate in building a democratic society);

- competences related to life in a multicultural society (the ability to recognize and accept differences, to respect others, to coexist with representatives of other cultures, languages and religions);

- competences in the area of oral and written communication, including knowledge of more than one language;

- competences related to the development of the information society (use of technologies, understanding possibilities and ways of their application, ability to critically perceive the information disseminated by media, ability to learn (Key competencies in Europe, p.11).

Within the "Definition and Selection of Competencies - DESECO" Project, initiated in 1997 by the Organization for Economic Cooperation and Development, the following categorical scheme comprising three categories was developed:

- "To use tools interactively" includes the competences: to use the language, symbols and texts in interaction; use knowledge and information in interaction, use technology in interaction;

- "To interact in heterogeneous groups" is to build relationships with others; work in a team, to resolve conflicts;

- "To act autonomously" - to act in a large dimension (taking into account the norms of society, understanding the consequences); develop and implement life plans and personal projects; protect rights, interests and needs (Definition and Selection of Competencies, 2003).

In 2006, the EU approved a European Reference Framework of Key Competences for Lifelong Learning comprising eight key competences, i.e. 
communication in the mother tongue; communication in foreign languages; mathematical competence and basic competences in science and technology; digital competence; learning to learn; social and civic competences; sense of initiative and entrepreneurship; cultural awareness and expression (European Reference Framework of Key Competences for Lifelong Learning, 2006, p. 3).

This resulted in the reforms in the EU member states to bring education more closely in line with the "key competence" approach. As indicated in the European Commission and EURYIDICE report "Developing Key Competences and School in Europe: Challenges and Opportunities for Policy" (2012) the EU countries recognize the importance of foundation skills for employment, social inclusion and further learning. Consequently, they actively implement the competence-based education in the aspects of national strategies adoption, shifting curricula to the learning outcomes approach, finding relevant models to assess the students' key competences.

In 2017 international organizations indicated progress in implementing competence-based education in Romania. OECD reports that the curriculum framework for primary and secondary education published in December 2015 sets competency-based learning as a key principle and defines eight main categories of competencies in line with the key competencies for lifelong learning set out in the EU 2006 Reference Framework. This work is led by the IES, who has developed the overall framework for the new curriculum and are coordinating the development of the new curriculum for each grade and domain (Kitchen et al., 2017, p. 49). The European Commission underlines that following the implementation of a competence-based curriculum for primary education, Romania has started phasing in a new curriculum for lower secondary education (with 5 th grade in the current school year). A modernization of the curriculum for upper secondary education is planned as well, to train teachers to teach the modernized curriculum (Education and Training Monitor 2017: Romania, 2017, p. 7).

A great number of initiatives in many EU countries aiming at supporting the use of the Reference Framework is indicated within the KeyCoNet, a European policy network. However, in the "Review of the 2006 Framework of Key Competences for Lifelong Learning" (2017) it is stated that a large 
share of the EU population currently lacks a sufficient level of basic and digital skills to be employable and take part in social life. The EU benchmark that fewer than $15 \%$ of 15 -year-olds should be under-skilled in reading, mathematics and science by 2020 has not yet been reached. Actually, the latest 2015 PISA data show that the EU as a whole is seriously lagging behind in all three domains and has taken a step backward. Finally, $40 \%$ of employers report difficulties in finding candidates with the right skills, many of them stressing a lack of transversal skills among job applicants (p. 8).

The update of the " 2006 Reference Framework" is aimed at better supporting the education and training systems for development of competence-based education as well as increasing in the number of people equipped with key competences. Through the "Council Recommendation on Key Competences for Lifelong Learning" (January 17, 2018), the European Commission proposed the updated set of key competences necessary for employability, personal fulfilment, active citizenship and social inclusion - literacy competence; languages competence; mathematical competence and competence in science, technology and engineering and; digital competence; personal, social and learning competence; civic competence; entrepreneurship competence; cultural awareness and expression competence (Annex to the Proposal, p. 2).

Therefore, the introduction of the competence-based education in the EU is characterized by:

- consistency - it has been in place for more than 10 years, covering all levels, i.e. EU level, national levels, levels of educational institutions, public;

- integrity - a competency-based education strategy is part of the overall EU knowledge-building strategy and integrated into all key educational policy-making documents. It is a part of the New Skills Agenda for Europe, it is linked to ET 2020, the Copenhagen process on vocational education and training (VET), European Agenda for Adult Learning and the Agenda for the Modernisation of Europe's Higher Education Systems. It also relates to the European Pillar of Social Rights stressing the role of education in enabling citizens to take full part in the labour market and society (Review, p. 7); 
- openness - is constantly upgraded to meet the challenges of the economy and European societies.

\section{European dimension of the competence approach in the Ukrainian education}

The European competence approach has a great influence on the Ukrainian education. In fact, it has caused the shift of the knowledge paradigm (dominated in the Soviet education) to the pupil-centred and results-oriented paradigm. Firstly, the discussion of a competence and competence-based education started within the UNDP in Ukraine projects "Education Innovation and Renewal for Improved Wellbeing and Poverty Reduction" (2002-2003) and "Education Policy and Peer Education" (2004). In the books "Reform Strategy for Education in Ukraine: Educational Policy Recommendations" (Chapter "Competences as a Key to Educational Content Renewal") (2003) and "Competence-based Approach in the Modern Education: World Experience and the Ukrainian Prospects (Education Policy Library)" (2005) (published within the framework of these projects), the Ukrainian scholars Nadiya Bibik, Olena Lokshyna, Oksana Ovcharuk, Ludmyla Paraschenko, Olena Pometun, Oleksandra Savchenko, Svitlana Trubacheva, Lidiya Vaschenko and others under the umbrella of the Ministry of Education and Science of Ukraine launched the process of discussion, definition and selection of competences for the Ukrainian education and school in particular. Basically, the "Definition and Selection of Competencies" Project's list of competences was used as a basis to construct the national portfolio of key competences. However, it took time that the conceptual work done by the Ukrainian scholars became an integral part of the national educational policy and turned into practice. The 2006 European Reference Framework of Key Competences for Lifelong Learning played a crucial part for the definition of the key competences list at the national level and transformation of the national education on the competence basis - the new generation of the state standards - State Standard of the Primary General Secondary Education (2011) and State Standard of the Basic and Full General Secondary Education (2011) were competence-oriented. Firstly, at the national level an official list of competences was presented comprising: the civic, cultural, health saving, 
ICT, communication, aesthetic, art, technology, social competences, although there was still discussion around the definition of the notions of key, metasubject, subject competences. Challenges also comprised a gap between the declaration of a competence approach at the policy level and unreadiness of teachers to implement it in practice. Besides, slow transformation of textbooks into competence base can be named as a problem.

The final stage of harmonization of school education in Ukraine with European benchmarks in the aspect of competence-oriented education started with the adoption of the Concept of the Reform of Secondary Education "New Ukrainian School" (2016) proclaiming that new content of the new school will be based on competencies necessary for successful self-realization in the society (New Ukrainian School, p. 7).

The new Law of Ukraine "On Education" (2017) finally confirmed the European vector of the Ukrainian education development and the competence approach to the school education. The Law declares that the goal of the secondary education is a comprehensive development, upbringing and socialization of a person capable to live in a society and interact with nature, to have a desire for self-improvement and life-long learning, ready for conscious life choices and self-realization, responsibility, work activity and civic activity. The achievement of this goal is ensured through the formation of key competencies (Law of Ukraine "On Education” 2017). In the Law, the educational phenomenon of a competence combines knowledge and skills with other basic for today's life characteristics of a personality. The interpretation of a competence in Ukraine is based on the EU vision (table no. 1).

The State Standard of Primary Education, approved by the Resolution of the Cabinet of Ministers of Ukraine as of February 21, 2018, No. 87, anchors competence orientation of the primary school. The aim of primary education is the comprehensive development of a child, his/her talents, abilities, competences and transversal skills in accordance with age, individual psychophysiological characteristics and needs, formation of values, development of autonomy, creativity and curiosity as stated in the Standard (Postanova Kabinetu Ministriv Ukrainy, 2018). 
Table no. 1. Definition of competences

\begin{tabular}{|c|c|}
\hline $\begin{array}{l}\text { Definition of competences in the } \\
\text { European Reference Framework of } \\
\text { Key Competences for Lifelong } \\
\text { Learning (2006) }\end{array}$ & $\begin{array}{l}\text { Definition of competence in the Law } \\
\text { of Ukraine "On Education" (2017) }\end{array}$ \\
\hline $\begin{array}{l}\text { Combination of knowledge, skills and } \\
\text { attitudes appropriate to the context. } \\
\text { Key competences are those, which all } \\
\text { individuals need for personal fulfilment } \\
\text { and development, active citizenship, } \\
\text { social inclusion and employment. }\end{array}$ & $\begin{array}{l}\text { A dynamic combination of } \\
\text { knowledge, skills, skills, ways of } \\
\text { thinking, views, values, other personal } \\
\text { qualities, which determines the ability } \\
\text { of a person to successfully socialize, } \\
\text { carry out professional and / or further } \\
\text { educational activities. }\end{array}$ \\
\hline
\end{tabular}

It should be underlined the almost full correlation of the list of key competence in Ukraine with the 2006 European Reference Framework.

Table no. 2. List of key competences

\begin{tabular}{|c|l|}
\hline $\begin{array}{c}\text { List of key competences defined in the } \\
\text { European Reference Framework of Key } \\
\text { Competences for Lifelong Learning (2006) }\end{array}$ & $\begin{array}{c}\text { List of key competences defined in the } \\
\text { Law of Ukraine “On Education" } \\
\text { (2017) }\end{array}$ \\
\hline \multirow{2}{*}{$\begin{array}{c}\text { Communication in the mother tongue } \\
\text { Communication in foreign languages }\end{array}$} & $\begin{array}{c}\text { Fluency in the state language } \\
\text { Ability to communicate in mother tongue } \\
\text { in case it differs from the state language) } \\
\text { and foreign languages }\end{array}$ \\
\hline Mathematical competence and basic \\
competences in science and technology & $\begin{array}{l}\text { Mathematical competence } \\
\text { Competence in the area of natural } \\
\text { sciences, engineering and technology }\end{array}$ \\
\hline & Innovation \\
\hline Digital competence & Ecological competence \\
\hline Learning to learn & $\begin{array}{l}\text { Information and communication } \\
\text { competence }\end{array}$ \\
\hline & Life-long learning \\
\hline Social and civic competences & $\begin{array}{l}\text { Civil and social competences related to } \\
\text { the ideas of democracy, justice, equality, } \\
\text { human rights, well-being and a healthy } \\
\text { lifestyle, with the awareness of equal } \\
\text { rights and opportunities }\end{array}$ \\
\hline Cultural awareness and expression & Cultural competence \\
\hline Sense of initiative and entrepreneurship & Entrepreneurship and financial literacy \\
\hline
\end{tabular}




\begin{tabular}{|l|l|}
\hline $\begin{array}{c}\text { List of key competences defined in the } \\
\text { European Reference Framework of Key } \\
\text { Competences for Lifelong Learning (2006) }\end{array}$ & $\begin{array}{l}\text { List of key competences defined in the } \\
\text { Law of Ukraine "On Education" } \\
\text { (2017) }\end{array}$ \\
\hline & $\begin{array}{l}\text { The following skills are proclaimed } \\
\text { common for all competences: reading } \\
\text { with understanding, ability to express }\end{array}$ \\
own opinion orally and in writing, critical \\
and systematic thinking, ability to \\
logically justify a position, creativity, \\
initiative, ability to constructively \\
manage emotions, evaluate risks, make \\
decisions, solve problems, ability to co- \\
operate with other people.
\end{tabular}

So, the competence approach is identified as a priority at the legislative and strategic levels in Ukraine. This is evidenced by the concept "New Ukrainian School" (2016), the new Law "On Education" (2017), the State Standard of Primary Education (2018).

At the same time, there is no synchronization between the previously adopted and currently adopted legislative and strategic documents defining the educational policy in Ukraine in the aspects of competences. It is referred to competence definition as well as a list of key competencies that are to be harmonized.

A long-time gap between reforms in the EU and in Ukraine can be considered as a big challenge. In fact, in 2016 Ukraine started introducing the 2006 European Reference Framework. Accordingly, today, after the modernization of the EU Framework in 2018 the question arises about further modernizing the competence concept.

\section{Challenges accompanying competence education implementation in EU and in Ukraine}

The implementation of competence-based education is accompanied by many challenges. Large-scale discussions refer to a number of issues starting from the actual interpretation of the concept to the technologies of competence evaluation. 
In particular, Ronald G. Sultana initiates a discussion on the influence of the context on the formation of a competence. The question arises, says the scientist, as to whether the competences are fixed formations and whether they change under the influence of the context. The answer to this has serious consequences for the learning process, which, in the case of changing competencies under the influence of the context, should be adapted to it (Sultana, 2009, p. 22).

Another issue raised by Ronald G. Sultana is the correlation between knowledge and skills in the very structure of a competence and is about finding the optimal balance between these components. The problem here is the recent emphasis on the performance component of a competence and levelling the cognitive one.

Discussions are also underway on the relation among the so-called general/ key/meta-competencies and subject/ narrow ones, especially in the sector of vocational education. It is found that in the case of paying more attention to the formation of general competencies during the study, the ability of individuals to work is increased, and with the emphasis on the formation of narrow professional ones, the quality of performance of professional duties is increased.

There is still the aspect of "learning" of competences which remains unanswered. This refers to whether all individuals are able to master the competences. Franz E. Weinert, in his turn, raises the question of the different nature of competences, for instance, the ability to learn, and the subject competence. Hence - problems in the development of the assessment system. Martin Mulder, Tanja Weigel and Kate Collins (2006), while summarizing critical comments from different countries, note that criticism in England still concentrated upon behavioural roots of the competences - in practice, the implementation of a competence approach is often reduced to assessing a pupil's ability to demonstrate acquired skills in practice.

In Germany, the main criticism concerns, first, the weakening of the role of the knowledge component of a competence. Another problem is the underdevelopment of technologies to assess the mastering of a person's competency. 
There are also assessment challenges in France. In particular, in the professional training the assessment of competence mastering by individuals often occurs in the learning environment, which calls into question its validity for employers. In the Netherlands, as in Germany, the problem is considered to be the levelling of the significance of educational subjects and interdisciplinary subjects that play an important role not only in the formation of a knowledge component of competence, but also in the metacharacteristics of personality - the ability to learn, etc. (Mulder, Weigel, \& Collins, 2006, pp. 18-19).

The scholars of the National Academy of Educational Sciences of Ukraine in the paper "National Report on the Status and Prospects for the Development of Education in Ukraine" (2016) underline the slow implementation of the competence approach in the Ukrainian education. They state that the competence approach has not been adequately reflected in curricula and textbooks, the relationship between key and subject competences needs to be further elaborated, as well as approaches to assessing the key and subject competences mastered by pupils (Natsional'na dopovid' pro stan i perspektyvy rozvytku osvity v Ukrayini, p. 52).

\section{Conclusion}

The competence approach in education proclaimed by the European Community at the beginning of the 21st century as an instrument to prepare young citizens for life and work in a knowledge society and as a tool for countries to meet the challenges of globalization, has been widely accepted in Ukraine. The EU approach has a decisive impact on the formation of a national competency education concept in Ukraine.

The common features of the competence reform in the EU and in Ukraine are the introduction of a coherent strategy that is implemented at the highest level of educational policy, i.e. at the supranational level in the EU and at the national level in Ukraine.

Ukraine, like EU, proclaims a holistic approach to the introduction of competencies, i.e. it foresees the introduction of a full range of key 
competences rather than focusing on specific ones.

On the other hand, the competence concept has not yet become an integral part of the lifelong system in Ukraine. The level of the competence concept introduction into the secondary, vocational, high, adult education is different both at the level of strategies and in practice. Also, efficient monitoring of the achievements and challenges of the competence education introduction in Ukraine is not present.

\section{References}

- Biemans, H., Nieuwenhuis, L., Poell, R., Mulder, M., \& Wesselink, R. (2017, October 30). Competence-based VET in the Netherlands; Background and pitfalls, Berufs- und Wirtschaftspadagogik. Retrieved from http://www.bwpat.de/ 7eu/biemans_etal_nl_bwpat7.shtml.

- Cabinet of Ministers of Ukraine. (2018). Resolution on the adoption of the State Standard of Primary Education (as of February 21, 2018, \# 87) - ост нов про з твердження ерж вного ст нд рту поч ткової освіти. Kуіv, Cabinet of Ministers of Ukraine. Retrieved from http://zakon5.rada.gov.ua/laws/ show/87-2018-\%D0\%BF\#n12.

- European Commission. (2017). Education and Training Monitor 2017: Romania 2017. Luxembourg: Publications Office of the European Union.

- European Commission. (2017). Review of the 2006 Framework of Key Competences for Lifelong Learning. Consultation Strategy. Retrieved from https://ec.europa.eu/education/sites/education/files/key-competencesconsultation-2017-strategy_en.pdf.

- European Commission. (2018). Annex to the Proposal a Council Recommendation on Key Competences for Lifelong Learning as of January 17, 2018, Brussels, COM (2018) 24 final. Retrieved from _https://ec.europa.eu/ education/sites/education/files/annex-recommendation-key-competenceslifelong-learning.pdf.

- European Commission/EACEA/Eurydice. (2012). Developing Key Competences at School in Europe: Challenges and Opportunities for Policy. Eurydice Report. Luxembourg: Publications Office of the European Union.

- EURYDICE. (2002). Key Competencies. A developing concept in general compulsory education. Brussels: Eurydice.

- Hager, P. (1998). Is there a cogent philosophical argument against competency standards? In P. Hirst \& P. White (Eds.), Philosophy of Education: Major 
Themes in the Analytic: Problems of Educational Content and Practices. Florence, KY, USA: Routledge.

https://ec.europa.eu/education/sites/education/files/annex-recommendationkey-competences-lifelong-learning.pdf.

- Hutmacher, W. (1997). Key competencies in Europe, Report \# DECS/SE/Sec(96)-43 of the Symposium (Berne, Switzerland, 27-30 March, 1996). A Secondary Education for Europe Project, Council for Cultural Co-operation, Strasbourg, France.

- Kitchen, H. et al. (2017). Romania 2017. OECD Reviews of Evaluation and Assessment in Education: Romania OECD Publishing, Paris. Retrieved from https://www.unicef.org/romania/OECD_Reviews_en_pt_web.pdf. https:// doi.org/10.1787/9789264274051-en.

- Kremen V.H., Luhovyy V.I., Hurzhiy A.M., Savchenko O.Ya. (Eds). (2016). National Report on the state and prospects of education development in Ukraine (original title: ціон льн доповідь про ст н і перспективи розвитку освіти в кр їні). Kyiv, Pedahohichna Dumka.

- La Rosa, M. (2014). EU: Education policies and third countries. Civilian power or just foreign policy? Paper retrieved from Lund University Libraries, http://lup.lub.lu.se/student-papers/record/4451074.

- Lawn, M., \& Grek, S. (2012). Europeanizing Education: governing a new policy space. Oxford: Symposium Books Ltd.

- Lisbon European Council 23 and 24 March 2000 Presidency Conclusions (2000). Retrieved from http://www.europarl.europa.eu/summits/lis1_en.htm.

- Ministry of Education and Science of Ukraine. (2003). Reform Strategy for Education in Ukraine: Educational Policy Recommendations. Document elaborated with the support of United Nations Development Programme, International Renaissance Foundation, Open Society Institute (Budapest), Kyiv: K.I.S.

- Ministry of Education and Science of Ukraine. (2016). New Ukrainian School. Conceptual Principles of Secondary School Reform. Kyiv.

- Mulder, M., Weigel, T., \& Collins, K. (2006). The concept of competence concept in the development of vocational education and training in selected EU member states. A critical analysis. Journal of Vocational Education and Training, $59(1), 65-85$.

- Ovcharuk, O. (Ed). (2004). Competency-based approach in modern education: world experience and Ukrainian prospects: Educational policy series. Kiev, K.I.S.

- Recommendation of the European Parliament and of the Council of 18 December 2006 on key competences for lifelong learning. (2006/962/EC). Official Journal of the European Union, 30.12.2006, L 394/10-394/18 EN. 
Retrieved from http://eur-lex.europa.eu/legal-content/EN/TXT/PDF/ ?uri=CELEX:32006H0962 \&from=EN.

- Rychen, D. S., \& Hersh Salganik L. (Eds) (2003). Key Competencies for a Successful Life and a Well-Functioning Society. Germany: Hogrefe \& Huber.

- Sahlberg, P. (2012, October 23). Global Educational Reform Movement is here!. Retrieved from https://pasisahlberg.com/global-educational-reform-movementis-here/.

- Smith, M. K. Competence and Competency (1996, 2005). The Encyclopedia of Informal Education Retrieved from http://infed.org/mobi/what-iscompetenceand-competency/.

- Sultana, R. G. (2009). Competence and competence frameworks in career guidance: complex and contested concepts, The International Journal for Educational and Vocational Guidance, 9:15-30. Retrieved from https:// www.um.edu.mt__dataassets/pdf_file/0015/60414/Competence_IJEVG.pdf.

- Zakon, U. (2017, October 23). Pro osvitu. Retrieved from http://zakon3.rada.gov. ua/laws/show/2145-19.

- Zimnyaya, I.A. (2004). Klyuchevyye kompetentnosti kak rezul'tativno-tselevaya osnova kompetentnostnogo podkhoda v obrazovanii. M.: Issledovatel'skiy tsentr problem kachestva podgotovki spetsialistov.

The online version of this article can be found at: http://revped.ise.ro/category/2018-en/

\section{(cc) $B \mathrm{Y}-\mathrm{NC}-\mathrm{SA}$}

This work is licensed under the Creative Commons Attribution-NonCommercial-ShareAlike 4.0 International License.

To view a copy of this license, visithttp://creativecommons.org/licenses/by-ncsa/4.0/ or send a letter to Creative Commons, $P O$ Box 1866, Mountain View, CA 94042, USA.
Versiunea online a acestui articol poate fi găsită la:http://revped.ise.ro/category/2018-ro/

\section{(cc) BY-Ne-ZA}

Această lucrare este licen iată sub Creative Commons Attribution-NonCommercial-ShareAlike 4.0 International License.

Pentru a vedea o copie a acestei licen e, vizita $i$ http://creativecommons.org/licenses/by-nc-sa/4.0/ sau trimite i o scrisoare către Creative Commons, PO Box 1866, Mountain View, CA 94042, SUA. 